\title{
SISTEM PENGGAJIAN GURU DAN TENAGA KEPENDIDIKAN \\ DI TK. 'AISYIYAH BUSTANUL ATHFAL I \\ KOTA PROBOLINGGO MENURUT PRINSIP-PRINSIP \\ AKAD IJARAH
}

\author{
Mohammad Arifin \\ Abdul Wahab \\ Universitas Muhammadiyah Surabaya \\ Email : arifinmohammad.etizayse@gmail.com
}

\begin{abstract}
During 2016 to 2019 there were many demonstrations carried out by educators and educational staff with a minimum guarantee of receiving monthly and no government allowance. This demonstration of educators is a silent proof of the inability of the government in the welfare of educators who need a non-PNS level, the complexity of being a PNS educator also cannot be solved by only teaching for more than 10 years. Anxiety like this certainly occurs in every region. To answer this we can answer through the payroll Sistem of educators and education personnel in kindergarten. ABA I Probolinggo City? and how is the implementation of the principles of the ijarah contract in kindergarten payroll systems. ABA I Kota Probolinggo according to the principles of the ijarah contract?

To answer this question, this type of research is used (field field research) with a qualitative method. The data collection techniques used in this study include observation, interviews, and document study. The data that has been collected is then compiled and analyzed using descriptive methods, which describes the concept of implementing the payroll Sistem and the principles of the ijarah contract in kindergarten. 'Aisyiyah Bustanul Athfal I Probolinggo City.

The results of this study state that the implementation of the payroll Sistem and the implementation of the principles of the charity ijarah contract in the payroll Sistem in kindergarten. 'Aisyiyah Bustanul Athfal I City of Probolinggo is still general. Although in its application both parties have each benefited, this has not met the provisions of the ijarah agreement in accordance with sharia economic law.
\end{abstract}

Keywords : Principles of Ijarah Agreement and Payroll Sistem

\section{PENDAHULUAN}

Penggajian pendidik dan tenaga kependidikan merupakan bentuk pemberian kompensasi yang diberikan oleh pimpinan kepada yang dipimpinnya. Kompensasi tersebut bersifat financial dan merupakan yang utama dari bentuk-bentuk kompensasi yang ada bagi karyawan. ${ }^{1}$

\footnotetext{
${ }^{1}$ Susilo Martoyo, Manajemen Sumber Daya Manusia, (Yogyakarta: PT. BPFE, 1987), 130.n
}

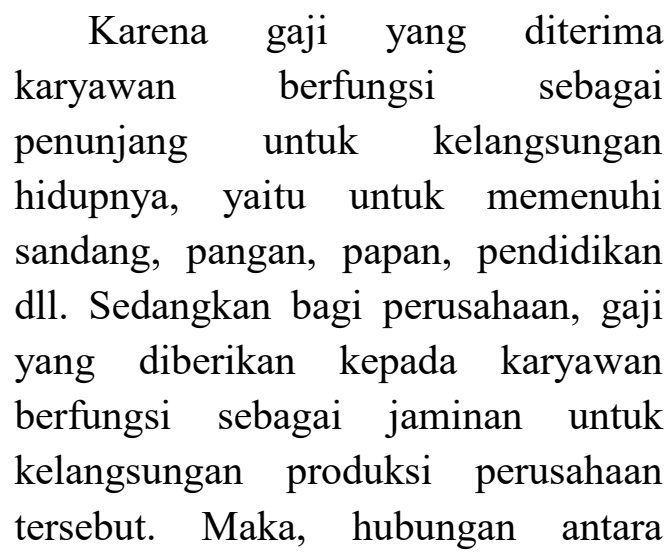


pengusaha dengan pekerja harus terjaga baik dan saling memahami kebutuhan masing-masing. Majikan harus memberikan gaji yang sesuai dengan pekerjaan dan pekerja bekerja sesuai dengan perjanjian.

Salah satu bentuk muamalah adalah perjanjian kerja atau kesepakatan kerja bersama antara manusia sebagai penyedia jasa manfaat atau tenaga pada satu pihak, dengan manusia lain sebagai penyedia pekerjaan dipihak lain. Hal demikian dilakukan guna melakukan suatu produksi, dengan ketentuan pihak pekerja akan mendapatkan kompensasi berupa gaji. Kegiatan itu dalam literatur fiqh disebut dengan akad Ijarah al-'amal, yaitu sewa menyewa jasa tenaga manusia. ${ }^{2}$

Pada tahun 2016 tepatnya bulan Februari, pendidik dan tenaga kependidikan se Indonesia melakukan demo di depan istana negara. Menagih janji Menteri Pemberdayaan Aparatur Negara dan Reformasi Birokrasi Yuddy Chrisnandi yang dianggap ingkar janji, hal itu dikarenakan sebuah janji yang disampaikan oleh Yuddy Chrisnandi akan mengangkat guru honorer K2 2015-2019 secara bertahap pada 15 september 2015 yang sampai saat itu belum terealisasi.

Kejadian serupa juga terjadi pada tahun 2018 bulan Oktober, demo guru honorer yang meminta diangkat menjadi Calon Pegawai Negeri Sipil (CPNS). Selanjutnya pada tahun 2019 mencuat kabar di daerah-daerah terjadi kasus guru honorer yang lolos Perjanjian Kerja (P3K) ternyata masih mendapat gaji dari tempat ia mengajar

${ }^{2}$ Abdurrahman al-Jaziri, kitab al-Figh 'ala al-Mazahib alArba'ah (Beirut : Dar al Fikr, 2003),73 dengan kisaran antara Rp. $250.000-$ Rp. 500.000 per bulan.

Demo pendidik tersebut menjadi bukti bisu tidak mampunya pemerintah dalam mensejahterakan pendidik yang berada dilevel non PNS, rumitnya menjadi Pendidik PNS juga tidak bisa diselesaikan hanya dengan mengajar lebih dari 10 tahun. Kegelisahan seperti ini pastinya terjadi disetiap daerah. Lalu bagaimana dengan Lembaga pendidikan swasta ! yang tentu didalamnya juga banyak terdapat pendidik dan tenaga kependidikan yang gajinya masih sedikit atau bahkan jauh mendekati gaji pendidik PNS atau Upah Minimum Regional (UMR).

Padahal kalau kita melihat gaji pendidik Malaysia sangat berbanding terbalik, hal ini terungkap dalam peluncuran Kongres Guru Indonesia 2010 di Sampoerna School Of Education Building Atase pendidikan Kedutaan Besar Malaysia Dato' Paduka Junaidy mengatakan gaji guru mula di Malaysia berjumlah 1.405 RM ditambah tunjangan rutin 340 RM, totalnya sekitar Rp. 4.941.222, gaji ini diberikan kepada guru muda lulusan D3 yang baru mengajar Guru muda ini berada di grade DGA 29. Di tahap akhir grade ini, gajinya bisa mencapai Rp 10.682.685,36. Jika guru juga naik golongan atau grade, gajinya pun akan naik hampir Rp 2 juta. $^{3}$

Berbeda dari Indonesia, guru baru yang mengajar di sekolah negeri maupun swasta tidak bisa menyamai hal tersebut. Hal ini miris sekali,

\footnotetext{
${ }^{3}$ Glo.28/04/2010.Uh, Gaji Guru Mula di Malaysia Rp 5 Juta. https://edukasi.kompas.com/read/2010/04/28/11503066/Uh..Gaj i.Guru.Mula.di.Malaysia.Rp.5.Juta. 21/07/2020
} 
Malaysia yang dulunya membutuhkan guru dari Indonesia untuk menunjang peningkatan pendidikan di Malaysia. Namun saat ini ternyata Indonesia bisa dibilang tertinggal dari muridnya.

TK. ABA I adalah Lembaga Pendidikan dibawah naungan 'Aisyiyah, dimana 'Aisyiyah adalah salah satu Organisasi Otonom (Ortom) milik Muhammadiyah. Jadi dapat disimpulkan bahwa TK. ABA I ini adalah Lembaga Pendidikan milik Muhammadiyah.

Muhammadiyah pada laporan Muktamar Makassa tepatnya periode 2010-2015 memberikan menginformasikan bahwa Muhammadiyah dalam bidang Pendidikan memiliki 176 perguruan tinggi, 14346 TK ABA-PAUD, 2604 SD/MI, $1772 \quad$ SM/MTs, 1143 SMA/SMK/MA, 71 SLB, 102 pondok pesantren, dan 15 Sekolah Luar Biasa. ${ }^{4}$

Untuk itu penulis tertarik untuk meneliti tentang bagaimana pelaksanaan implementasi akad ijarah dalam penentuan gaji di Lembaga TK. ABA I, apakah sudah sesuai dengan konsep Akad Ijarah ataukah belum, dan bila mana dalam pelaksanaannya seperti diatas bagaimana dampaknya kepada pendidik dan tenaga kependidikan di sekolah tersebut. Oleh karenanya, ketika melihat permasalahan diatas, peneliti tertarik untuk melakukan penelitian tentang "Sistem Penggajian Guru dan Tenaga Kependidikan di TK. 'Aisyiyah Bustanul Athfal I Kota Probolinggo Menurut Prinsip-prinsip Akad Ijarah".

${ }^{4}$ Pimpinan Pusat Muhammadiyah. 2015. Laporan Disajikan Dalam Muktamar Muhammadiyah Ke-47. Makassar : 3-7 Agustus.
Menganalisis sistem penggajian guru dan tenaga kependidikan di TK. ABA I Kota Probolinggo dan sistem penggajian guru dan tenaga kependidikan di TK. ABA I Kota Probolinggo menurut prinsip-prinsip akad ijarah menjadi fokus utama dalam penelitian ini.

\section{KERANGKA TEORI}

A. Pengertian akad

Al-'Aqd berasal dari kata 'aqada ya'qidu - 'aqdan; jamaknya adalah aluqûd. Secara bahasa al-'aqd bermakna ar-rabth (ikatan), asy-syadd (pengencangan), at-taqwiyah (penguatan). Jika dikatakan, 'aqada alhabla (mengikat tali), maksudnya adalah mengikat tali satu dengan yang lain, mengencangkan dan menguatkan ikatannya. Al-'aqdu juga bisa bermakna al-'ahdu (janji) atau al- mîtsâq (perjanjian).

Adapun al-'uqdah (jamaknya al'uqad) adalah obyek ikatan atau sebutan untuk sesuatu yang diikat ${ }^{5}$. Pada awalnya kata 'aqada digunakan untuk benda padat seperti tali dan bangunan, namun kemudian dengan majaz isti'ârah kata ini juga diterapkan untuk selainnya seperti: 'aqd al-bay' (akad jual-beli), 'aqd al- 'ahd (akad perjanjian), 'aqd an-nikâh (akad nikah). Dalam konteks ini, 'aqada dimaknai sebagai ilzâm (pengharusan) dan iltizâm (komitmen) atau irtibâth (pertautan). ${ }^{6}$

B. Syarat Rukun Akad Ijarah

Berdasarkan Fatwa DSN MUI NO: 09/DSN-MUI/IV/2000 tentang Pembiayaan adalah ; 1. Ijarah Syarat

${ }^{5}$ Zubair Kamal M. \& Hamid A., "Eksistensi Akad Dalam Transaksi Keuangan Syariah, ” Jurnal Hukum Diktum Vol. 14, no. 1 (2016): 45-54.

${ }^{6}$ Ibid., 56 
Rukun Ijarah berdasarkan Fatwa DSN MUI : a) Sighat Ijarah yaitu ijab dan qabul berupa pernyataan dari kedua belah pihak yang berakad (berkontrak), baik secara verbal atau dalam bentuk lain, b) Pihak-pihak yang berakad: terdiri atas pemberi sewa/pemberi jasa dan penyewa/pengguna jasa. c) Obyek akad ijarah adalah manfaat barang dan sewa dan manfaat jasa dan upah. 2. Ketentuan Obyek Ijarah, a) Obyek ijarah adalah manfaat dari penggunaan barang dan/atau jasa, b) Manfaat barang atau jasa harus bisa dinilai dan dapat dilaksanakan dalam kontrak. c) Manfaat barang atau jasa harus yang bersifat dibolehkan (tidak diharamkan).

Kesanggupan memenuhi manfaat harus nyata dan sesuai dengan syari'ah. e) Manfaat harus dikenali secara spesifik sedemikian rupa untuk menghilangkan jahalah (ketidaktahuan) yang akan mengakibatkan sengketa. f) Spesifikasi manfaat harus dinyatakan dengan jelas, termasuk jangka waktunya. Bisa juga dikenali dengan spesifikasi atau identifikasi fisik. $^{7}$

\section{Macam-macam Ijarah}

Ijārah ada dua macam yaitu Ijārah 'ain dan Ijārah dzimmah : 1. Ijārah 'ain adalah Suatu akad sewa-menyewa atas manfaat yang bersinggungan langsung dengan bendanya, seperti mempekerjakan orang tertentu untuk melakukan sesuatu. 2. Ijārah dzimmah adalah Akad sewa-menyewa dalam bentuk tanggungan, misalnya menyewa jasa penjahit untuk membuat baju atau jasa buruh untuk membangun rumah atau melakukan pekerjaan lainnya. Dalam hal ini, sebagai tanda persetujuan akad pihak kedua

${ }^{7}$ Dewan Syariah Nasional MUI, Pembiayaan Ijarah (Jakarta: 2000) mengucapkan shighat qabul, Aku terima, "atau "Aku terima kontrak kerja tersebut". 8

D. Jenis-jenis Ijarah

Akad ijarah diklasifikasikan menurut objeknya menjadi dua macam, yaitu ijarah terhadap manfaat benda-benda nyata yang dapat diindera dan ijarah terhadap jasa pekerjaan. Jika pada jenis pertama ijarah bisa dianggap terlaksana dengan penyerahan barang yang disewa kepada penyewa untuk dimanfaatkan, seperti menyerahkan rumah, toko, kendaraan, pakaian, perhiasan, dan sebagainya untuk dimanfaatkan penyewa. ${ }^{9}$

Sedangkan pada jenis kedua, ijarah baru bisa dianggap terlaksana kalau pihak yang disewa (pekerja) melaksanakan tanggung jawabnya melakukan sesuatu, Seperti membuat rumah yang dilakukan tukang, memperbaiki komputer oleh teknisi komputer, dan sebagainya. Dengan diserahkannya barang dan dilaksanakannya pekerjaan tersebut, pihak yang menyewakan dan pihak pekerja baru berhak mendapatkan uang sewa dan upah.

Pada ijarah tenaga kerja berlaku hukum harga/upah, dan pada ijarah benda berlaku hukum jual beli. Terdapat berbagai jenis ijarah, antara lain ijarah 'amal, ijarah 'ain/ijarah muthlaqah, ijarah muntahiya hittamlik, dan ijarah multijasa. ${ }^{10}$ 1. Ijarah 'Amal, yaitu Ijarah 'amal digunakan untuk memperoleh jasa dari seseorang dengan membayar upah atas jasa yang diperoleh. Pengguna jasa disebut mustajir dan pekerja disebut ajir, dan

\footnotetext{
${ }^{8}$ Wahbah Al-Zuhaili, Fiqih Imam Syafi'i, hlm. 51.

9 A. Wangsawidjaja Z, Pembiayaan Bank Syariah, 214

${ }^{10}$ Fathurrahman Djamil, Penerapan Hukum Perjanjian. 56
} 
upah yang dibayarkan kepada ajir disebut ujrah. Dalam bahasa Inggris dari ujrah adalah fee.

2. Ijarah 'Ain atau Ijarah Muthlaqah (Ijarah Murni), yaitu Ijarah 'ain adalah jenis ijarah yang terkait dengan penyewaan asset dengan tujuan untuk mengambil manfaat dari aset itu tanpa harus memindahkan kepemilikan dari aset itu. Dengan kata lain, yang dipindahkan hanya manfaat (usufruct). Ijarah 'ain di dalam bahasa Inggris adalah term leasing. Dalam hal ini, pemberi sewa disebut mujir dan penyewa adalah mustajir dan harga untuk memperoleh manfaat tersebut disebut ujrah.

Dalam akad ijarah ain, tidak terdapat klausul yang memberikan pilihan kepada penyewa untuk membeli aset tersebut selama masa sewanya atau di akhir masa sewanya. Pada ijarah 'ain yang menjadi objek akad sewamenyewa adalah barang. ${ }^{11}$.

E. Bentuk Akad Ijarah

Dilihat dari objek Ijarah berupa manfaat suatu benda maupun tenaga manusia Ijarah itu terbagi kepada dua bentuk, yaitu : ${ }^{12} 1$. Ijarah 'ain, yakni ijarah yang berhubungan dengan penyewaan benda yang bertujuan untuk menganmbil manfaat dari benda tersebut tanpa memindahkan kepemilikan benda tersebut, baik benda benda bergerak, seperti menyewa kendaraan maupun benda tidak bergerak, seperti sewah rumah. 2. Ijarah amal, yakni ijarah terhadap perubahan atau tenaga manusia yang diistilahkan dengan upah mengupah, ijarah ini

\footnotetext{
${ }^{11}$ Ibid, 156

12 Rozalinda, Fikih Ekonomi Syariah : Prinsip dan Implementasinya pada Sektor Keuangan Syariah, (Jakrta; Rajawali Pers; 2016), 131
}

digunakan untuk memperoleh jasa dari seseorang dengan membayar upah atau jasa dari pekerjaan yang dilakukan.

Jadi istilah sewa biasanya digunakan dalam memanfaatkan benda sedangkan istilah upah digunakan dalam memanfaatkan tenaga". ${ }^{13}$ Manfaat sesuatu dalam konsep ijarah mempunyai definisi yang sangat luas meliputi imbalan atas manfaat suatu benda atau upah terhadap suatu pekerjaan tertentu. Jadi ijarah merupakan transaksi terhadap manfaat suatu barang dengan suatu imbalan, yang disebut sewa-menyewa.

Dan ijarah juga mencakup transaksi terhadap suatu pekerjaan tertentu, yaitu imbalan yang disebut juga dengan upah- mengupah.

\section{F. Berakhirnya Akad}

Adapun hal-hal yang yang bisa menyebabkan batal atau berakhirnya akad Ijarah, yaitu: 1. Salah satu pihak meninggal dunia. Ini merupakan pendapat ulama mazhab Hanafi. Bagi mazhab ini manfaat yang diperoleh dari Ijarah adalah sesuatu yang terjadi secara bertahap dan ketika meninggalnya salah satu pihak manfaat tersebut tidak ada dan tidak sedang dimilikinya.

Maka mustahil untuk bisa diwariskan. Sedangkan menurut Jumhur Ulama, akad Ijarah tidak batal dengan wafatnya salah seorang yang berakad, karena menurut Jumhur Ulama manfaat itu boleh diwariskan dan Ijarah sifatnya mengikat kedua belah pihak.

2. Terjadinya kerusakan pada barang sewaan, seperti: Rumah terbakar atau mobil hilang. 3. Tenggang waktu yang disepakati dalam akad Ijarah telah

\footnotetext{
${ }^{13}$ Hendi Suhendi, Fiqih Mu'amalah, (Jakarta : PT Raja
} Grafindo Persada, 2011), 2 
berakhir. Apabila yang disewakan itu rumah, maka rumah itu dikembalikan kepada pemiliknya dan apabila yang disewa itu jasa seseorang maka ia berhak menerima upahnya. 4. Menurut jumhur ulama, uzur yang boleh membatalkan akad Ijarah itu hanyalah apabila objeknya mengandung cacat atau manfaat yang dituju dalam akad itu hilang, seperti kebakaran atau dilanda banjir. Sedangkan menurut Ulama Hanafiyah apabila ada uzur dari salah satu pihak, seperti rumah yang disewakan disita Negara karena terkait hutang yang banyak, maka akad Ijarah menjadi batal. 5. Berakhir dengan Iqalah yaitu pembatalan akad atas dasar kesepakatan antara kedua belah pihak. Hal ini karena Ijarah merupakan akad pertukaran harta dengan harta yang diambil manfaatnya. ${ }^{14}$

\section{METODE PENELITIAN}

\section{A. Jenis Penelitian}

Dalam penelitian ini peneliti akan menggambarkan secara penuh bagaimana implementasi ijarah dalam penentuan gaji di TK. ABA I Kota Probolinggo. kemudian dianilisis menggunakan hukum ekonomi syariah, untuk mencapai tujuan tersebut peneliti menggunakan analisis deskriptif kualitatif.

$$
\text { Penelitian deskriptif adalah }
$$
penelitian yang bertujuan untuk membuat deskrispi atau gambaran mengenai fakta-fakta, sifat-sifat, serta hubungan antara fenomena yang diselidiki lalu dianalisis. ${ }^{15}$ Penggunaan metode ini dipandang sebagai "prosedur

\footnotetext{
14 Chairuman Pasaribu dan Suhrawardi K. Lubis, Hukum Perjanjian Dalam Islam. Cetakan Ketiga. (Jakarta: PT. Sinar Grafika Offset. 2004), 52

${ }^{15}$ Saifudin Azwar, Metode Penelitian, (Yogyakarta: Pustaka Pelajar Offset, 1998), 128.
}

penelitian yang diharapkan dapat menghasilkan data deskriptif berupa kata - kata tertulis atau lisan dari sejumlah orang dan perilaku yang diamati". ${ }^{16}$ Jenis penelitian yang digunakan dalam penelitian ini adalah penelitian lapangan (field research). Penelitian lapangan bertujuan mempelajari secara intensif tentang latar belakang keadaan sekarang dan interaksi suatu sosial, individu, kelompok, Lembaga dan masyarakat. ${ }^{17}$ Penelitian lapangan pada penelitian ini dilakukan di TK. ABA I Kota Probolinggo.

B. Sumber Data Penelitian

1. Sumber Data Primer, adalah data yang diperoleh langsung, seperti hasil dari wawancara dari subjek penelitian dengan mengenakan alat pengukuran atau alat pengambilan data langsung pada subjek sebagai sumber informasi yang di cari. ${ }^{18}$ 2. Sumber Data Sekunder, Sumber Data sekunder adalah data penelitian yang diperoleh peneliti secara tidak langsung melalui media perantara (di peroleh dan di catat oleh orang lain).

Data sekunder peneliti peroleh dari laporan keuangan dan slip gaji tiap bulan pada Lembaga TK. ABA I Kota Probolinggo. informan dalam penelitian ini terdiri dari informan kunci dan informan pendukung: a) Informan kunci adalah Kepala TK dan Bendahara TK. ABA I Kota Probolinggo. b) Informan pendukung adalah guru dan tenaga kependidikan TK. ABA I Kota Probolinggo.

\footnotetext{
${ }^{16}$ Ahmad Tanzeh, Metode Penelitian Praktis, ( Jakarta: PT. Bina Ilmu, 2004 ), 39

${ }^{17}$ Husaini Usman dan Purnomo Setiady Akbar, Metodologi Penelitian Sosial, (Jakarta: Bumi Aksara, 2004), 5

${ }^{18}$ Saifuddun Azwar, Metode Penelitian, (Yogyakarta: Pustaka Belajar, 2004), 91
} 


\section{Data Penelitian}

Data penelitian ini bersifat kualitatif, yaitu data yang disajikan dalam bentuk kata verbal bukan dalam bentuk angka. ${ }^{19}$ yang termasuk data kualitatif dalam penelitian ini yaitu gambaran umum obyek penelitian, meliputi: Sejarah singkat berdirinya, letak geografis obyek, Visi dan Misi, struktur organisasi, keadaan guru, keadaan siswa, keadaan sarana dan prasarana, serta Sistem penggajian gaji di TK. 'Aisyiyah Bustanul Athfal I Kota Probolinggo.

D. Teknik Pengumpulan Data

Teknik pengumpulan data dalam penelitian ini adalah sebagai berikut :

1. Observasi, adalah kegiatan pemuatan perhatian terhadap suatu objek dengan menggunakan seluruh alat indra. ${ }^{20}$

Dalam melaksanakan pengamatan ini sebelumnya peneliti akan mengadakan pendekatan dengan subjek penelitian sehingga terjadi keakraban antara peneliti dengan subjek penelitian. Observasi dalam penelitian dilakukan terhadap Sistem implementasi ijarah Sistem penentuan gaji di TK. ABA I Kota Probolinggo. 2. Wawancara, Wawancara adalah percakapan dengan maksud tertentu. Percakapan dilakukan oleh dua pihak, yaitu pewawancara (interviewer) yang mengajukan pertanyaan dan pewawancara (interviewee) yang memberikan jawaban atas pertanyaan itu ${ }^{21}$.

3. Dokumentasi, Dokumentasi merupakan catatan peristiwa yang

\footnotetext{
${ }^{19}$ Noeng Muhadjir, Metodologi Penelitian Kualitatif,

(Yogyakarta : Rakesarasin, 1996), 2.

${ }^{20}$ Suharsimi Arikunto, Prosedur Penelitian, (Jakarta:Renika Cipta, 2010), 199.

${ }^{21}$ Moleong, Lexy J, Metodologi Penelitian Kualitatif, (Bandung : PT Remaja Rosdakarya Offset, 2007), 168
}

sudah berlalu, dokumen bisa berbentuk tulisan, gambar-gambar atau bentuk dokumen monumental dari seseorang. Menurut Suharsimi Arikunto metode dokumentasi adalah 'mencari data, presentasi, notulen rapat, legger, agenda dan sebagainya'"22.

D. Instrumen Penelitian

Instrumen adalah alat atau fasilitas yang digunakan penelitian dalam mengumpulkan data agar pekerjaannya lebih mudah dan hasilnya lebih baik, sehingga mudah diolah. ${ }^{23}$ Alat bantu sebagai in instrumen yang dimaksud yaitu kamera, telepon genggam untuk recorder, pensil, ballpoint, buku dan buku gambar.

\section{E. Teknik Analisis Data}

Seiring dengan jenis penelitian yaitu penelitian deskriptif kualitatif, dalam analisis data di lakukan dengan cara "mendeskripsikan". Analisis data merupakan proses mencari dan menyusun secara sistematis data yang diperoleh kemudian menyimpulkannya sehingga mudah dipahami. ${ }^{24}$ Setelah data terkumpul dan diolah sedemkian rupa, Langkah selanjutnya adalah menganalisis data dan mengambil kesimpulan dari data dan hasil penelitian.

Adapun untuk mengelola data - data kualitatif ini dengan menggunakan metode deskriptif, observasi terus menerus, reduksi data, penyajian dan penarikan kesimpulan atau verifikasi sebagai berikut :

1. Metode Deskriptif, adalah penelitian yang bertujuan untuk

\footnotetext{
22 Suharsimi Arikunto, Prosedur Penelitian Kualitatif

Pendekatan Suatu Praktek, (Jakarta:2002) 107

${ }^{23}$ Arikunto, Prosedur Penelitian: Suatu Pendektan

Praktek. Edisi Revisi V, (Jakarta: Rineka Cipta,2002), 136

24 Sugiono, Metode Penelitian Kualitatif, Kualitatif dan $R \& D$, cet. IV (Bandung: Alfabeta, 2008), 244.
} 
membuat deskripsi atau gambaran mengenai fakta-fakta, sifat-sifat serta hubungan antara fenomena yang diselidiki lalu dianalisis. ${ }^{25}$

Setelah dilakukan secara pengamatan dan pemahaman secara mendalam pada data hasil penelitian, peneliti akan menggambarkan tentang fakta-fakta yang berhubungan dengan implementasi ijarah pada Sistem penggajian di TK. ABA I Kota Probolinggo.

2. Reduksi Data, adalah Data yang diperoleh dari lapangan jumlahnya tidak sedikit. Oleh karena itu data data tersebut perlu dicatat secara terperinci dan secara teliti. Dan untuk hal tersebut perlu dilakukan analisis data melalui reduksi data. Reduksi data adalah "Proses pemilihan, pemutusan perhatian dan penyederhanaan, pengabstrakan dan transformasi data mentah yang didapat dari catatan catatan penulis lapangan"26 3 . Penarikan kesimpulan atau verifikasi, Pada saat kegiatan analisis data yang berlangsung secara terus menerus selesai dikerjakan, baik yang berlangsung didalam lapangan maupun setelah selesai dari dalam lapangan. Langkah selanjutnya yaitu melakukan penarikan kesimpulan dari data-data yang telah diperoleh. Yang bertujuan untuk mengarahkan hasil kesimpulan ini berdasarkan hasil analisis data yang telah di lakukan sebelumnya, baik data yang diperoleh dari catatan lapangan, observasi, dokumentasi dan lain-lain yang didapatkan pada saat melaksanakan kegiatan dilapangan. ${ }^{27}$

${ }^{25}$ Saifuddin Azwar, Metode Penelitian, (Yogyakarta: Pustaka Pelajar, 2011), 128.

${ }^{26}$ Ahmad Tanzeh dan Suyitno, Dasar-dasar Penelitian,

(Surabaya: Elkaf, 2006), 175

27 Ibid., 177

\section{HASIL PENELITIAN DAN PEMBAHASAN}

A. Gambaran Umum Obyek Penelitian

TK. ABA I Kota Probolinggo adalah Lembaga Pendidikan Anak Usia Dini (PAUD) yang berada di bawah naungan Organisasi Otonom (Ortom) 'Aisyiyah dengan induk organisasinya adalah Muhammadiyah.

Sejak Tahun 2008 TK. ABA I bertempat dijalan Jalan KH. Mansyur No. 109 Kelurahan Mangunharjo Kecamatan Mayangan Kota Probolinggo berpindah yang sebelumnya bertempat di jalan Kartini No. 15 Kelurahan Sukabumi Kecamatan Mayangan Kota Probolinggo. Mempunyai 26 Guru dan Tenaga Kependidikan dan setiap tahunnya TK. ABA I Kota Probolinggo menerima 120 peserta didik.

Sejak berdiri pada tahun 1952 hingga saat ini, TK. ABA I Kota Probolinggo yang sebelumnya menumpang lahan di MI Muhammadiyah I Kota Probolinggo di Jalan Diponegoro No.15 Kelurahan Sukabumi Kecamatan Mayangan Kota Probolinggo sudah pindah ke lahan yang baru pada tahun 2008 dengan perincian lokasi sekolah sebagai berikut ; 1.Tahun 2008 TK. ABA I pindah ke Jalan KH. Mansyur No. 109 Kelurahan Mangunharjo Kecamatan Mayangan Kota Probolinggo 2. Lahan ini diwaqafkan ke Muhammadiyah oleh dr. Moh. Saleh dengan luas tanah dan bangunan $1.920 \mathrm{~m} 2$. 3. Menjadi Gusus TK Inti pada 7 lembaga TK lainnya.

B. Data Peserta Didik dan Tenaga kependidikan 
Terdapat 4 kelas dimasing masing kelompok, kelompok A berjumlah 85 anak, kelompok B berjumlah 105 anak, data ini diambil pada tahun pelajaran 2019/2020. Jumlah tenaga pendidik terdapat 16 orang dan tenaga kependidikan berjumlah 10 orang.

C. Penyajian Data

\section{Informan}

Informan kunci diambil dari kepala TK dan Bendahara TK. Informan pendukung diambil dari 4 tenaga pendidik senior dan 2 tenaga kependidikan senior, jumlah keseluruhan informan adalah 8 orang.

D. Sistem Penggajian

1. Akad kerja

TK. ABA I Kota Probolinggo merupakan lembaga TK yang perekrutan kerjanya tidak bisa dilakukan sendiri. Hal ini dikarenakan TK. ABA I berada dibawah naungan ortom 'Aisyiyah yang mempunyai Majelis Pendidikan Dasar dan Menengah yang mengatur perekrutan kerja tersebut.

Pelamar kerja diwajibkan untuk menghadiri wawancara kerja dengan kepala TK. Hal ini dimaksudkan untuk memberikan informasi lebih banyak terkait pekerjaan yang menjadi tanggungjawabnya. TK. ABA I dalam hal akad kerja dilakukan dengan sebuah pernyataan dari kepala TK kepada pelamar kerja.

Wawancara kerja juga dilakukan untuk menginformasikan besaran gaji yang akan diterima. Karena setiap pendidik atau tenaga kependidikan baru akan bekerja pada masa percobaan selama 1 tahun, dengan gaji pertiga bulannya berbeda, jika pada masa percobaan tidak ada pihak yang merasa dirugikan masa percobaannya lolos dan akan diberikan Surat Keputusan dari Majelis Pendidikan Dasar Menengah sebagai bukti sah sudah menjadi pendidik dan tenaga kependidikan TK. ABA I dan berhak mendapatkan gaji sebagaimana mestinya.

2. System penggajian

TK. ABA I Kota Probolinggo dalam Sistem penggajiannya diterapkan berdasarkan ketentuan yang sudah berlaku, bukan pada suatu akad, dimana gaji untuk awal bulan sebesar Rp. 300.000, selanjutnya dinaikkan $\mathrm{Rp}$. 100.000 dan begitu seterusnya hingga masa percobaan tersebut selesai, hal tersebut sebelumnya sudah disampaikan secara terbuka saat wawancara kerja. hal tersebut dihitung berdasarkan rumus pada tabel gaji yaitu ada masa kerja, tunjangan jabatan, tunjangan tambahan, tunjangan keluarga, transport, lauk pauk dan taspen juga

Penentuan gaji di TK ABA I Kota Probolinggo tidak serta merta kepala TK menerapkannya. Pada awalnya kepala TK dengan bendahara 1 akan membuat Rincain Anggaran Pendapatan Belanja (RAPB) bulanan dan pertahun yang disesusaikan dengan keadaan keuangan, nantinya kepala TK akan menyampaikan RAPB tersebut pada rapat pengurus yang dihadiri Ketua Majelis Pendidikan Dasar dan Menengah tingkat Daerah dan Cabang, Komite, Koordinator Majelis Pendidikan Dasar dan Menengah.

Keputusan akhir dalam penentuan RAPB tergantung pada hasil rapat pengurus tersebut, jika pengurus ingin merubah beberapa point maka kepala TK dan Bendahara akan melakukan perubahan sesuai yang disepakati dalam rapat tersebut. 
Sumber penghasilan TK. ABA I dalam menggaji pendidik dan tenaga kependidikan hanya dari pembayaran uang gedung dan SPP perbulan peserta didik. Dalam 3 tahun ini biaya pendaftaran peserta didik baru, daftar ulang dan SPP perbulan selalu sama. Biaya pendaftaran sebesar Rp. 4.025.000, daftar ulang sebesar Rp. 2.960.000 dan SPP perbulan sebesar Rp. $305.000 .^{28}$

Biaya yang dikeluarkan oleh walimurid tersebut dialokasikan kepada fasilitas pembelajaran anak, perawatan Gedung serta menggaji pendidik dan tenaga kependidikan, karena memang di TK. ABA I kota probolinggo ini belum ada yang Pegawai Negeri Sipil (PNS).

Proses penerimaan gaji di TK. ABA I Kota Probolinggo diberikan pada tanggal akhir bulan, namun apabila tanggal akhir bulan jatuh pada hari ahad atau tanggal merah maka penerimaan gaji akan dilakukan dihari sebelumnya. Sebelum penerimaan gaji kepala TK dan Bendahara rutin menanyakan kepada pendidik dan tenaga kependidikan terkait pemotongan gaji bagi mereka yang mempunyai tanggungan hutang ke TK. ABA I Kota Probolinggo.

3. Pelaksanaan Prinsip-Prinsip Akad Ijarah pada Sistem Penggajian di TK. ABA I Menurut Hukum Ekonomi Syariah

Akad ijarah adalah salah satu transaksi untuk melakukan kerjasama, entah itu persewaan barang atau pembayaran upah/gaji. Jika berbicara tentang prinsip - prinsip akad ijarah itu artinya kita bicara tentang implementasi

${ }^{28}$ Dokumen RAPB Tahunan dan Bulanan TK. ABA I atau praktek dilapangan dalam sebuah perjanjian. seperti yang disampaikan oleh kepala TK dan Bendahara 1 bahwasannya dalam sistem penggajian di TK. ABA I Kota Probolinggo tidaklah menggunakan suatu akad apapun, karena memang mereka belum mengenal macam macam akad suatu transaksi, yang dipahami adalah sebuah perjanjian atau akad yang dilakukan dengan ungkapan pernyataan dari dua belah pihak dengan adanya ijab dan qobul seperti pada umumnya.

TK. ABA I Kota Probolinggo dalam perjanjiannya telah dilakukan pada saat wawancara kerja dengan memberikan banyak informasi terkait beban tanggungjawab pekerjaan dan besaran gaji yang akan didapat.

E. Analisis Data

1. Analisis Sistem penggajian pendidik dan tenaga kependidikan di TK. ABA I Kota Probolinggo

Berdasarkan hasil wawancara dan pengamatan secara mendalam pada data rincian atau tabel gaji beberapa pendidik dan tenaga kependidikan TK. 'Aisyiyah Bustanul Athfal I Kota Probolinggo tersebut tentang Sistem penggajian yang dilakukan, maka analisis peneliti dibagi menjadi dua yaitu; a) Akad kerja, Dalam proses perekrutan pendidik dan tenaga kependidikan di TK. ABA I selalu diawali wawancara langsung dengan Kepala TK. Saat wawancara tersebut kepala TK memberikan banyak informasi terkait beban tanggungjawab dan jam kerjanya. Didalam hubungan kerjasama tentu kedua belah pihak harus melakukan ijab dan qobul yang sering kita sebut akad sebagai syarat sahnya suatu kerjasama. 
Kepala TK secara terbuka menjelaskan tugas pokok dan fungsi serta besaran gaji yang akan terima setiap bulannya pada beban tanggungjawab yang akan dipegang selama bekerja di TK. ABA I. hal ini menunjukkan pihak TK telah menerapkan hukum positif dalam bentuk kerjasama kerja.

TK. ABA I Kota Probolinggo dalam proses perjanjiannya telah terpenuhi dalam hal ijab dan qobul, dikarenakan saat wawanca telah terucap suatu pernyatan penawaran dari kepala TK yang disanggupi oleh pelamar kerja atau pendidik dan tenaga kependidikan tersebut.

Hal ini sesuai dengan Akad tersebut dikatakan sah apabila telah memenuhi syarat dan rukunnya, rukun akad yang dimaksud adalah adanya pihak yang berakad yang dilakukan baik secara verbal atau dalam bentuk hal lain, obyek akad serta tujuan akadnya. ${ }^{29}$

b) Pelaksanaan sistem penggajian, Pada dasarnya dalam hubungan kerja tentu kedua pihak harus sama sama diuntungkan, apabila salah satu pihak merasa dirugikan maka perjanjian hubungan kerja tersebut tidaklah sehat, tentu hal demikian dilarang dalam agama islam.

Besaran gaji yang ditentukan oleh TK haruslah berdasarkan kebutuhan hidup layak dengan memperhatikan, pertumbuhan ekonomi, serta upah minimum daerahnya.

Proses penerapan Sistem penggajiannya dimulai dari Kepala TK dan bendahara yang membuat RAPB tahunan dan bulanan, terdapat biaya pendidikan peserta didik baru, daftar

\footnotetext{
${ }^{29}$ Fatwa DSN.2000.Pembiayaan Ijarah.Jakarta:DSN MUI
}

ulang kelompok B, biaya SPP perbulan, gaji perbulan tiap pendidik dan tenaga kependidikan. Semuanya itu hitung berdasarkan jumlah peserta didik tiap tahun pelajaran.

Tabel yang digunakan pada Sistem penggajiannya menggunakan ketentuan TK sendiri dengan menyesuaikan keadaan keuangan, yaitu adanya besaran gaji pokok, tunjang keluarga, jabatan, fungsional, sturktural dan tugas tambahan, begitu juga dengan biaya makan dan transport serta BPJS, dll.

TK. ABA I Kota Probolinggo juga melakukan perbedaan besaran gaji yang didapat setiap orangnya. Pendidik dan tenaga kependidikan yang baru bekerja akan menjalani masa percobaan selama 6 bulan dengan gaji setiap 3 bulannya berbeda. Setelah masa percobaan tersebut selesai maka akan mendapatkan SK Pengangkatan sebagai GTY atau PTY dengan gaji yang sudah bisa dihitung dalam tabel gaji setiap bulannya,

Pendidik dengan masa kerja paling lama 23 tahun, mendapatkan tunjangan keluarga serta pendidikan yang sudah S1 mendapatkan gaji sebesar Rp. 1.7500.000. sedang pendidik atau tenaga kependidikan yang masih baru bisa jadi kurang dari Rp. 1.000.000. hal ini bisa saja terjadi jika tingkat pendidikannya masih SMA atau dibawahnya.

Meski belum mampu untuk memberikan gaji sesuai Upah Minimum Regional (UMR), TK. ABA I kota probolinggo selalu berupaya untuk memberikan yang terbaik dalam Sistem penggajiannya. Hal ini bisa dibuktikan dengan penjelasan dari Kepala TK dan bukti yang telah dirasakan oleh pendidik dan tenaga kependidikan di 
TK. ABA I, diantaranya adalah : a) Meski belum mampu untuk memberikan gaji sesuai Upah Minimum Regional (UMR), TK. ABA I kota probolinggo selalu berupaya untuk memberikan yang terbaik dalam Sistem penggajiannya. Hal ini bisa dibuktikan dengan penjelasan dari Kepala TK dan bukti yang telah dirasakan oleh pendidik dan tenaga kependidikan di TK. ABA I, diantaranya adalah : Pendidik dan tenaga kependidikan yang telah bekerja lebih dari 2 tahun akan mendapatkan dana Taspen. b) Gaji ke-13 rutin diberikan setiap tahunnya pada bulan Agustus.

c) Mendapatkan pembagian dari hasil BOP DAK Non Fisik atau BOP Daerah.

d) Setiap lembur kerja diberikan uang lembur. e) Mendapatkan snack dan makan siang. f) Gaji diberikan tepat waktu pada tanggal akhir bulan, apabila tanggal akhir bulan jatuh pada hari ahad, maka gaji akan diberikan pada hari sabtu.

2. Analisis Sistem Penggajian Guru dan Tenaga Kependidikan di TK. ABA I Kota Probolinggo Menurut Prinsip-Prinsip Akad Ijarah

Akad ijarah adalah salah satu dari sekian banyak akad pada Fatwa Dewan Syariah Nasional (DSN) Majelis Ulama Indonesia (MUI), akad ijarah bisa dikatakan sah apabila rukun syarat ijarahnya terpenuhi. Kedua belah pihak wajib melakukan ijab qobul, berupa pernyataan dari kedua pihak yang berakad (berkontrak), baik secara verbal atau dalam bentuk lain.

Dalam hal ini TK. ABA I Kota Probolinggo dalam melakukan kontrak kerja saat wawancara terjadi sebuah ijab dan qobul atau pernyataan dari kedua belah pihak tanpa adanya surat kontrak kerja. Saat guru atau tenaga kependidikan tersebut telah lolos dalam tes wawancara maka akan diberlakakukan masa kerja percobaan selama 6 bulan atau selama 1 semester, jika dirasa dari kedua belah pihak tidak merasa dirugikan atau kinerja guru atau tenaga kependidikan tersebut bagus.

Maka selanjutnya sebagai tanda sah bekerja di lembaga tersebut kepala TK akan merekomendasikan guru atau tenaga kependidikan kepada Majelis Pendidikan Dasar dan Menengah Pimpinan Daerah 'Aisyiyah untuk diberikan Surat Keterangan (SK) Kerja sebagai Guru Tetap Yayasan yang dikeluarkan oleh Majelis Pendidikan Dasar dan Menengah Pimpinan Daerah 'Aisyiyah Kota Probolinggo..

Sistem penggajian di TK. ABA I tidak berdasarkan acuan Upah Minumum Regional (UMR) atau bisa dibilang Sistem penggajian yang diterapkan oleh TK. ABA I adalah rumusan atau ketentuan gaji yang dibuat sendiri oleh TK ABA I dengan ketentuan yang berlaku di lembaga tersebut dengan proses persetujuan dari Pimpinan Daerah 'Aisyiyah Kota Probolinggo, Pimpinan Cabang 'Aisyiyah Kecamatan Mayangan dan Komite TK yang dilakukan saat pertemuan rapat Rencana Pendapatan Anggaran Belanja (RAPB) Tahunan.

Kemudian dalam proses akad penggajiannya terhadap guru dan tenaga kependidikan disampaikan secara lisan kepada guru dan tenaga kependidikan saat wawancara kerja.

Hal-hal yang terdapat dalam Sistem penggajian TK. ABA I sebenarnya hamper sama pada umumnya, namun yang berbeda adalah adanya kolom 
taspen pada tabel gaji bagi guru dan tenaga kependidikan,taspen ini diberikan kepada guru dan tenaga kependidikan yang telah bekerja minimal 2 tahun, diberikannya gaji ke13 kepada guru dan tenaga kependidikan yang telah bekerja minimal 1 tahun, mendapatkan tambahan gaji bagi guru dan tenaga kependidikan yang lembur kerja.

Penelitian ini mengacu pada akad ijarah amal yang jenis dan bentuk akad ijarahnya bisa terlaksana kalau guru dan tenaga kependidikan melaksanakan tanggungjawabnya melakukan suatau pekerjaan yang telah disepakati bersama, yaitu mengajar peserta didik, melaksanakan tugas tanggungjawab lainnya sebagai guru dan tenaga kependidikan,pekerjaan pada umumnya dibidang tenaga kependidikan,

Terdapat banyak ketentuan untuk menerepakan akad ijarah amal diantaranya adalah terpenuhinya obyek akad ijarah yang diantaranya adalah manfaat jasa harus bisa dinilai dan dapat dilaksanakan dalam bentuk kontrak, dalam hal ini yang dimaksud adalah gaji berupa uang, adanya ungkapan lembaga kepada guru dan tenaga kependidikan untuk memenuhi manfaat sesuai dengan syari'ah, dalam hal ini yang dimaksud adalah ijab dan qobul, jangka waktu bekerja atau berakhirnya akad itu wajib disampaikan saat perjanjian kerja.

Meskipun pada umumnya sistem penggajiannya sudah baik, namun hal ini masih belum cukup untuk memenuhi ketentuan prinsip-prinsip akad ijarah.

Sistem penggajian guru dan tenaga kependidikan di TK. ABA I Kota Probolinggo yang diterapkan masih menggunakan cara atau sistem penggajian secara umum, hal tersebut masih belum sesuai dengan ketentuan prinsip-prinsip akad ijarah amal dalam hukum ekonomi syariah yang rukun syaratnya wajib terpenuhi, yaitu adanya ijab, qobul dan kontrak kerja.

A. Kesimpulan

1. Sistem penggajian yang digunakan oleh TK. ABA I Kota Probolinggo adalah perumusan Sistem gaji setiap pendidik dan tenaga kependidikan dengan nominal berbeda sesuai masa kerja dan beban tanggungjawab yang disusun oleh kepala TK dan bendahara yang mendapat persetujuan dari Pimpinan Cabang 'Aisyiyah, Pimpinan Daerah 'Aisyiyah dan Komite TK.

2. Pelaksanaan prinsip-prinsip akad ijarah amal dalam Sistem penggajian di TK. 'Aisyiyah Bustanul Athfal I Kota Probolinggo masih bersifat umum dikarenakan belum memenuhi ketentuan akad ijarah sesuai hukum ekonomi syariah.

\section{B. Saran}

Keseimbangan dalam bentuk kerja sama sesuai prinsip hukum islam adalah niscaya untuk terapkan. Hal ini terutama menjawab problematikaproblematika yang dihadapi setiap lembaga pendidikan. Mensejahterakan pendidik dan tenaga kependidikan tentu menjadi salah satu fokus lembaga, akad ijarah bisa menjadi pilihan yang tepat, namun baik dalam hubungan kerjasama dalam pekerjaan dan implikasi terhadap ekonomi setiap individu, posisinya sebagai pemberi kerja atau penerima kerja, semua itu adalah aktivitas hukum ekonomi islam yang harus menuju kepada kemaslahatan bersama. 



\section{DAFTAR PUSTAKA}

Susilo Martoyo. 1987. Manajemen Sumber Daya Manusia, Yogyakarta : PT. BPFE.

Abdurrahman al-Jaziri. 2003. kitab al-Fiqh 'ala al-Mazahib al-Arba'ah. Beirut : Dar al Fikr.

Glo.28/04/2010.Uh, Gaji Guru Mula di Malaysia Rp 5 Juta. https://edukasi.kompas.com/read/2010/04/28/11503066/Uh..Gaji.Guru.Muladi.Mala ysia.Rp.5.Juta. 21/07/2020

Pimpinan Pusat Muhammadiyah. 2015. Laporan Disajikan Dalam Muktamar Muhammadiyah Ke-47, Makassar : 3-7 Agustus.

Zubair Kamal M. \& Hamid A., 2016. "Eksistensi Akad Dalam Transaksi Keuangan Syariah". Jurnal Hukum Diktum.Volume 14.

A.Wangsawidjaja Z. 2013. Pembiayaan Bank Syariah, Jakarta : : Gramedia Pustaka Utama

Fathurrahman Djamil, 2013. Penerapan Hukum Perjanjian Dalam Transaksi di Lembaga Keuangan Syariah, Jakarta : Grafika

Rozalinda, 2016. Fikih Ekonomi Syariah : Prinsip dan Implementasinya pada Sektor Keuangan Syariah, Jakarta; Rajawali Pers.

Hendi Suhendi,2016. Fiqh Mu'amalah, (Jakarta: PT. Raja Grafindo Persada)

Chairuman Pasaribu dan Suhrawardi K. Lubis. 2004. Hukum Perjanjian Dalam Islam. Cetakan Ketiga. Jakarta: PT. SinarGrafika Offset

Rahman, Afzalur. Economic Doctrines of Islam, Terjemahan Soeroyo Nastangin, "Doktrin Ekonomi Islam", Jilid 2, 1995. Yogyakarta: Dana Bhakti Wakaf

Saifuddin Azwar. 2011. Metode Penelitian. Yogyakarta: Pustaka Pelajar

Ahmad Tanzeh dan Suyitno. 2006. Dasar-dasar Penelitian, Surabaya: Elkaf.

Husaini Usman dan Purnomo Setiady Akbar. 2004. Metodologi Penelitian Sosial, Jakarta: Bumi Aksara.

Noeng Muhadjir. 1996. Metodologi Penelitian Kualitatif. Yogyakarta : Rakesarasin

Suharsimi Arikunto. 2010. Prosedur Penelitian, Jakarta : Renika Cipta

Moleong, Lexy J. 2007, Metodologi Penelitian Kualitatif, Bandung : PT Remaja Rosdakarya Offset.

Arikunto Suharsimi. 2002. Prosedur Penelitian Kualitatif Pendekatan Suatu Praktek. Jakarta : 2002

Arikunto Suharsimi. 2002. Prosedur Penelitian : Suatu Pendektan Praktek. Edisi Revisi V. Jakarta : Rineka Cipta

Sugiono. 2008. Metode Penelitian Kualitatif, Kualitatif dan $R \& D$, cet. IV. Bandung : Alfabeta

Saifuddin Azwar. 2011. Metode Penelitian. Yogyakarta : Pustaka Pelajar

Ahmad Tanzeh dan Suyitno. 2006. Dasar-dasar Penelitian, Surabaya: Elkaf 